\title{
Pentecostalism and migration: A contextual study of the migrant Ghanaian Classical Pentecostal churches in South Africa
}

Author:
Peter White ${ }^{1}$
Affiliation:
'Department of Practical
Theology and Missiology,
Faculty of Theology,
Stellenbosch University,
Cape Town, South Africa
Corresponding author:
Peter White,
pwhite@sun.ac.za
Dates:
Received: 22 Aug. 2020
Accepted: 15 Dec. 2020
Published: 10 Feb. 2021
mobile device
to read online.
White, P., 2021,
'Pentecostalism and
migration: A contextual study
of the migrant Ghanaian
Classical Pentecostal
churches in South Africa',
HTS Teologiese Studies/
Theological Studies $77(4)$,
a6318. https://doi.org/
10.4102/hts.v77i4.6318
Copyright:
C 2021. The Authors.
Licensee: AOSIS. This work
is licensed under the
Creative Commons
Attribution License.

Pentecostal phenomenon from history has always moved with migration. Reading Acts 1:8, Jesus linked the baptism of the Holy Spirit with the migration of his disciples and the gospel from Jerusalem to Judea and Samaria and to the end of the earth. Migration has become a worldwide, multi-directional phenomenon which is reshaping the Christian landscape. In this light, the article discussed Pentecostalism and migration by using two Ghanaian Classical Pentecostal churches in South Africa as a case study. The article looked at their history, leadership development, transfer of missionaries from Ghana and its implications, their concept of contextualisation as well as some of their impact in South Africa. The article submits that it is time for both churches to start thinking of decolonising their foreign mission churches by helping them have autonomous status.

Contribution: The article contributes to the on-going body of knowledge and research on migration with special emphasis on African classical Pentecostalism and migration. The study used Ghanaian Classical Pentecostal Churches in South Africa as a case study.

Keywords: Pentecostalism; migration; South African churches; Ghanaian Classical Pentecostal Churches' Mission.

\section{Introduction}

Migration is an expression of the human aspiration for dignity, safety and a better future. It is part of the social fabric and part of our very make-up as a human family (World Economic Forum 2017:10). It is the movement of people across cities, countries or continents for the purpose of establishing permanent or temporary residence (Wild-Wood 2008:4). As people move from one place to the other, they go with their culture, language and religion. The Pentecostal phenomenon from history has always moved with migration. Reading Acts 1:8, Jesus linked the baptism of the Holy Spirit with the migration of his disciples and the gospel from Jerusalem to Judea and Samaria, and to the end of the earth. In Acts 2, where the early church experienced the manifestation of the indwelling of the Holy Spirit and began to speak with other tongues, as the Spirit gave them utterance, was linked to a period when Jews and visitors from various places of the world were present in Jerusalem to celebrate both the Passover and the Pentecost feast. After the Pentecost experience, we read of several missionary journeys being embarked upon by both the Apostles and other believers in the early church.

Further to the above, the history of the Azusa Street Revival in 1906 made it clear that people from America, Europe and several parts of the world received baptism in the Holy Spirit, and they spread Pentecostal teaching and theology in different countries. Within a short period, Pentecostalism spread to different countries and became the third force in Christendom (Lovett 1975:136; Miller 2006:21-31).

Migration has become a worldwide, multi-directional phenomenon which is reshaping the Christian landscape. The emergence of Pentecostal and charismatic movements from different localities is one of the most noteworthy characteristics of world Christianity today (Lorke \& Werner [eds] 2013:192).

Although migration comes with several legal, social and economic issues, Bevans (2013:158) submits that issues related to migrations and mission can be approached in three parts as follows:

- The practice of mission amongst migrants

- Migrants as subjects of mission - the mission of migrants 
- How the experience of migrations offers new understandings and paradigms of mission itself to the church.

In the light of the above, this article seeks to investigate Ghanaian Classical Pentecostal Churches in South Africa. The article discusses issues such as migration and God's missional agenda, history of Ghanaian Classical Pentecostal churches in South Africa, their pastoral appointment, leadership development, their approach to contextualisation of the gospel in South Africa as well as the transfer of missionaries from Ghana to South Africa and its challenges. The article concluded with the impact of migrant Ghanaian Classical Pentecostal churches in South Africa.

The focus of this article is not to discuss the challenges South Africa is facing with some migrant neo-prophetic/neoPentecostal/charismatic churches. Scholars such as Kgatle (2017, 2019) and Resane (2017) have dealt with this issue extensively. Further, churches under consideration in this article do not fall under the challenges being posed by some migrant neo-prophetic/neo-Pentecostal/ charismatic churches in South Africa. The track record of both the Church of Pentecost and the Christ Apostolic Church International attests to this fact both in Ghana and internationally. Both churches are also known to have structures in place to ensure sanity in the activities of their pastors. Their ministerial and administrative policy serves as guide for pastor in the administration of their pastoral duties (Christ Apostolic Church International 2018; The Church of Pentecost 2017).

The article contributes to the on-going body of knowledge and research on migration with special emphasis on classical Pentecostalism and migration. The study used Ghanaian Classical Pentecostal Churches in South Africa as a case study. The justification for using these churches for the study is that they are the leading and largest Classical Pentecostal Churches in Ghana with branches in South Africa. They were also used for the purposes of availability of documented information for the study.

\section{Migration and Missional Agenda of God}

Reading through the Bible, it is clearly noted that God has always used migration to achieve his missional agenda. Migration history, culled from the migration events recorded in the bible, can be put into the following categories:

- Migration from the Garden of Eden: The first form of human migration occurred when Adam and Eve were driven from the Garden of Eden leading to a loss of habitation (Gn 3:23; Walls 2014:19-20).

- Migration by divine command: Abraham and his descendants were born out of migration (Gn 12; Gn 23:4; Dt 26:5). God instructed Joseph to take Jesus Christ to Egypt until further notice (Mt 2:13-23).

- Situational migration: Some of the migrations recorded in the Bible were as a result of famine and security threats -
Abraham, Isaac and Jacob as well as their families settled at different places because of famine. Elimelech, Noami and their two sons went to Moab because of famine - (Ruth 1 and 2). Moses fled to Median to secure his life (Ex 2:11-15). Similarly, David on several occasions moved from one place to another for his personal security and safety.

- Forced migration: Joseph was betrayed and sold by his brothers. He later found himself in Egypt as a migrant (Gn 37).

- Migration through captivity and God's punishment: Abel became a wanderer as a result of God's punishment upon him for killing Cain (Gn 4:10-14). On several occasion, God allowed Israelites to be taken into captivity as a punishment for their disobedience (Walls 2014:20-21).

- Migration through missionary activities: Missionary journey of the early Church apostles and members.

Analysing the above migration events, one can conclude that the biblical migrations were caused by internal, external and spiritual factors. Example of the spiritual migration was the one recorded in Acts 8:39-40. Luke recorded that:

After Philip had baptized the Ethiopian Eunuch and when they came up out of the water, the Spirit of the Lord caught Philip away, so that the eunuch saw him no more; and he went on his way rejoicing. But Philip was found at Azotus. And passing through, he preached in all the cities till he came to Caesarea. (Ac 8:39-40)

No matter how people migrated in the Bible from one place to the other, God's missional agenda was fulfilled. The forced migration and betrayal of Joseph later became an opportunity for Israel to be saved from hunger and famine (Gn 45:7-9). The presence of Israelites in Egypt for 400 years was part of God's missional agenda to make them a great nation. In Egypt, Israelites had the opportunity to learn nation-building and acquire possessions (Gn 15:13-16). The Book of Esther made us aware that God's missional agenda for sending Esther to King Xerxes' palace in Susa was to save the Jews from the plot of Haman to destroy them (Es 4:7-14; 8:1-4).

Further to the above, whilst the Israelites were exiled in Babylonia, God spoke through Prophet Jeremiah for them to know his missional agenda:

Thus says the Lord of hosts, the God of Israel, to all who were carried away captive, whom I have caused to be carried away from Jerusalem to Babylon:

Build houses and dwell in them; plant gardens and eat their fruit. Take wives and beget sons and daughters; and take wives for your sons and give your daughters to husbands, so that they may bear sons and daughters - that you may be increased there, and not diminished. And seek the peace of the city where I have caused you to be carried away captive, and pray to the Lord for it; for in its peace you will have peace ... For thus says the Lord: After seventy years are completed at Babylon, I will visit you and perform My good word toward you, and cause you to return to this place. For I know the thoughts that I think toward you, says the Lord, thoughts of peace and not of evil, to give you a future and a hope. (Jr 29:4-7, 10-11)

In the above scripture, God clearly informed the Israelites to properly integrate themselves in Babylon through hard work, 
building houses, owning properties and procreating. They were also informed to pray for the welfare of the country because the welfare of the Israelites is linked to the welfare of Babylon. It was during the 70 years of Babylonian exile that Nehemiah and Daniel had the opportunity to serve at influential posts, offering professional services and godly counsel to the kings (Neh 2:1; Dn 1:3-6; 5:13-26, 6:1-3). The end product of the Babylonian exile was that the walls of Jerusalem were built, as well as the Temple of Jerusalem.

In the New Testament, Jesus Christ told his disciples to go to all nations and make disciples (Mt 28:16-20). This intrinsically means that the followers of Jesus Christ were to migrate with the gospel to various parts of the world. In the Acts of the Apostles, God used the various missionary journeys of the Apostles and ministers in the early Church to spread his missional agenda to save the world through Jesus Christ. In a nutshell, God's missional agenda as written in the Bible is fulfilled through the movement of people and nations from one place to the other.

\section{Migrant Ghanaian Classical Pentecostal Churches in South Africa}

Classical Pentecostalism is a renewal movement within Protestant Christianity that places special emphasis on a direct personal experience of God through baptism with the Holy Spirit (Livingstone [ed.] 2013:461). Classical Pentecostal churches began in the West in 1906 as a result of the Azusa Street experience. Apostle Peter Newman Anim and his Tabernacle Church, which was started in 1917, are credited with the origins of classical Pentecostalism in Ghana (Larbi 2001:32-33; White 2016:252).

The labour of Peter Anim and his Tabernacle Church gave birth to the Christ Apostolic Church (currently known as the Christ Apostolic Church International), the Apostolic Church - Ghana and the Church of Pentecost (AsamoahGyadu 2005:23). The Church of Pentecost surfaced through a split in 1939 in the group because of doctrinal differences in the Christ Apostolic Church and the Apostolic Church, Gold Coast. The latter grew rapidly under Pastor James McKeown. The Assemblies of God, Ghana, the fourth mainline Classical Pentecostal church in Ghana, was founded by Rev. Lloyd and Margaret Shirer, the first Pentecostal missionaries sent by the American Assemblies of God Church to Ghana in 1931 after serving as missionaries in Burkina Faso (White 2016:253).

Hanciles (2008:248) argues that 'African immigrant Churches are characterized by a strong missionary vision that echoes the exalted aims of the earlier and still forceful Western missionary movement'. The understanding that Spirit baptism gives the power for witness was paramount amongst early members of the Church of Pentecost. This therefore, caused them to evangelise and build churches wherever they went. As a result, mission stations, or branches of the church were opened in foreign countries-not through the initiative of the church's mission department, or by an organised church rally or crusade, but by individuals and economic migrants, who had travelled to do their private businesses (Walker 2010:163, 165).

The Church of Pentecost (CoP) and the Christ Apostolic Church International (CACI) are currently the two Ghanaian Classical Pentecostal Churches operating in South Africa. In an interaction with Apostle Dela Quampah and Rev. Abraham Quarshie in August 2019, they noted that the purpose of both churches for establishing branches in South Africa is for mission purposes and to provide pastoral care to the Ghanaian community in South Africa. It is also a way to project the church for international recognition. This therefore, gives us a clear picture for the study of the missional presence of Ghana Classical Pentecostal churches in South Africa.

\section{Brief History of the Church of Pentecost, South Africa}

The Church of Pentecost is a multinational church with mission outposts in over 90 countries in Africa, Europe, North and South America, Europe, Asia and Australia. The South Africa mission was initiated by the then Deacon Evans Akuffo (currently a Pastor and missionary to Botswana) on 14 October 1990, in Umtata in the former Transkei homeland (The Church of Pentecost, South Africa 2019a).

Church of Pentecost - South Africa commenced with Brothers Augustus Amegbley, Stephen Soglo and Obeng Tuffoh. The first service was held on 10 February 1991 in a classroom at E. W. Pearce Junior Secondary Northcrest. From 18 to 22 June 1992, Apostle Opoku Onyinah, the then International Missions Director (IMD) visited the church. His visit was followed by the sending of the first missionary in the person of Pastor and Mrs. M. C. Asiedu who arrived on 18 July 1993. The church had her inaugural service on 25 July 1993, with 144 members present. Evans A. Akuffo was made an elder and became the National Deacon (The Church of Pentecost, South Africa 2019a).

The first National Executive Committee members were Pastor M. C. Asiedu - Chairman, Elder Evans A. Akuffo National Deacon, Elder Yirenkyi Gyeke Darko - National Secretary, Elder Benjamin Agyemang Coffie - Member, Elder S. F. Ayesu Koranteng - Member, Elder G. G. A. Smith Member and Elder Clement Obeng Tuffoh - Member (Markin 2018:232-233). Other missionaries who came in later from Ghana were Pastor Eric Nyamekye ${ }^{1}$ and wife, Apostle J.W.D. Cudjoe (2006-2011), Apostle E.K. Acquah (2011-2015), and Apostle Dr. Dela Quampah (2015-August 2019) (The Church of Pentecost, South Africa 2019a).

The church has since expanded in South Africa. It is currently made up of 14 administrative districts that comprise of a number of local assemblies. The Districts are Kempton Park, Pretoria, Johannesburg, Umtata, Bloemfontein, East London, Queenstown, Butterworth, Port Elizabeth, Cape Town, Durban, Witbank, Polokwane and Kokstad (The Church of Pentecost, South Africa 2019a).

1.Apostle Nyamekye is the current Chairman of the Church of Pentecost. 
According to the 2019 mid-year report of the CoP - South Africa, the church currently has 5345 memberships (Quampah 2019b:1). The church has 14 districts' pastors overseeing 66 assemblies (The Church of Pentecost, South Africa 2019c:1).

\section{A brief history of the Christ Apostolic Church International, South Africa ${ }^{2}$}

The initiative for the establishment of the Christ Apostolic Church International in South Africa was facilitated by the visit of Rev. Addae Kusi ${ }^{3}$ to Pretoria, from 26 July to 5 August 2002. He was then a special assistant to Apostle Michael Nimo, the then Chairman of the Christ Apostolic Church International.

On 26 November 2003, a worship place was secured at Sunnyside Galleries - room 105 - under the leadership of Rev. Joseph Sakyi. The early members of the church were Rev. (Lawyer) Amponsah Frimpong, ${ }^{4}$ Madam Beatrice Danso, Mrs. Evelyn Addo Bediako, Mr. Amanfo Dwumah, Mr. Jackey, Deacon Victor Addo, Mr. Akwasi Adu Amankwah, Mr. Kwasi Boateng and his wife.

By 2005, the church had a membership of 81 people. A new place of worship was therefore secured in Sunny Fair building to accommodate the growing membership of the church. In the light of the diverse cultural background of the membership of the church, the then minister Rev. Joseph Sakyi started English and Twi ${ }^{5}$ language services. Rev. Sakyi was transferred to Ghana in August, 2005.

Apostle Emmanuel Appenteng was therefore transferred from Ghana to South Africa as the Head of South African Missions in October 2005. During his tenure, the church grew to about 400 when he was transferred to the United States of America in 2012. During the 7 years of Apostle Appenteng's stewardship, he did his best to put administrative structures in place. He also established ministries such as the youth ministry, women's ministry and children's ministry. With the help of the Headquarters in Ghana, the church purchased her first mission house. Branches of the church were established in Johannesburg, Centurion, Soshanguve and many other branch churches.

When Rev. Patrick Asuah took over the management of the church from 2012 to 2014, the church experienced several challenges in leadership conflicts between him and Rev. Elijah Takyi Hanson, the then pastor in charge of CACIJohannesburg. The unresolved leadership challenge ended in Rev. Elijah Takyi Hanson breaking away and establishing his own church with the members of CACI Johannesburg. The Johannesburg church was later strengthened and a new church was

2.The History of CACl, South African Mission, was gathered through an interview with Rev. Abraham Quarshie, South African Mission Head, on 14 August 2019. Other information was gathered through annual reports and handing over notes from preceding pastors of the church.

3.As at the time of this study, Apostle Addae Kusi is the current Missions Director of the Christ Apostolic Church International.

4.Apostle Amponsah Frimpong is now the General Secretary of the Christ Apostolic Church International.

5.Twi is one of the popular spoken languages in Ghana. established at Witbank. Rev. Patrick Asuah also facilitated the purchase of a bus to help the mission activities of the church.

After the transfer of Rev. Patrick Asuah, Pastor Thabo Manyane was appointed as interim Pastor until the arrival of Rev. Abraham Quarshie from Ghana to Head the South African mission in October 2015. The leadership skills of Rev. Quarshie led to massive growth in the church. He restructured the administrative framework of the church by establishing the Southern Africa Management Committee with the following people as members:

- Rev. Abraham Quarshie - South African Mission Head and Chairman

- Pastor Thabo Manyane - National Secretary

- Elder Adrain Tang - Head of Christian Education

- Elder Elliot Agbollah - Financial Secretary

- Elder Emmanuel Samaglo - National Deacon

- Deaconess Dr. Tabea Manyane - Leader of Women Ministry.

The church has branches in Sunnyside, Heidelberg, Tembisa, Southgate, Johannesburg, Witbank, Klipfontein, Brits, Hazyview, Springs, Soshanguve, Mamelodi, Silverton, East London, as well as pilot branches nationwide. The church currently has a total membership of 2000 and above (Annual report of CACI South Africa 2018).

\section{Transfer of missionaries from Ghana to South Africa and its challenges}

Pastoral transfer is part of the policy of Classical Pentecostal Churches in Ghana. Their transfers are usually within Ghana and internationally. Although internal transfer is not a big issue, there is a big challenge when it comes to international transfers because of immigration requirements. It was noted that many of the missionaries being transferred from Ghana to South Africa for both churches were using temporary residency visa/permit.

The use of a visitor visa by missionaries in South Africa comes with several limitations on the pastor and the pastoral family. Challenges sometimes lead to the pastoral family (wife and children) being left behind in Ghana (White 2017:129-131). Further to this, the immigration law in South Africa does not allow one to change his or her visitor visa status within South Africa (Department of Home Affairs 2020). Moreover, should the pastor or missionary come to South Africa with his school-going children, they would be required to apply for a study permit in Ghana. This therefore, raises the question 'why can't the sending church apply for a work permit for the missionary?' Applying for a work permit for a missionary comes with other requirements that the sending church from Ghana and the receiving church in South Africa should provide.

Further, in case the wife of the missionary is a professional and would like to work in South Africa to support the family, 
it would be difficult, because she would be required to have a work permit, to write a professional examination or to be a member of a professional body in South Africa.

In the light of all these, the question one may ask is that is it necessary to keep sending long-term missionaries to South Africa after these churches have been in existence in South Africa for more than 20 years?

This brings us to how the early church and the Pauline Church handled some of these issues and how the early western missionaries handled them.

Reading the history of the missionary journey of the early church, it was clearly noted that after missionaries stayed in a particular place for some number of months or years, they would train the local people or indigenes to take over the leadership of the church. Leaders of the home or mother church would only come in for few days or months to strengthen the church (Ac 14:21-28; Tt 1:5). Paul gave us another idea of handling foreign mission through the use of bi-vocational ministry or tent-making ministry (Ac 18:1-3, Ac 20:34).

The history of the early western missionaries to West Africa shows us that after the missionaries had established churches and locally trained leaders, they gradually handed over the leadership and management of those churches to the locally trained ministers (Anderson et al. [eds] 1994).

I believe the above information has a lot to tell us about moving on from religious colonisation to decolonising the churches - by training indigenes or appointing people with required residence permit to be long term missionaries. The Church of Pentecost is making a lot of effort to achieve the concept of decolonising their churches in foreign countries by developing those churches and their local leaders to take over the leadership and management of the churches. Their international mission policy says 'the ongoing granting of autonomy to nations which meet the appropriate criteria will be continued' (The Church of Pentecost 2014:59). Currently the Church of Pentecost has been established in 99 countries in the world, including Ghana, with two of the nations, Benin and Cote d'Ivoire, being autonomous.

\section{Leadership development}

Leadership formation and development are very important components of every organisation. The key to the formation of missional communities is their leadership (Roxburgh 1998:183). Reading the ministerial formation of Jesus Christ, it was noted that going to the synagogue to study was part of his regular practice (Lk 2:41-47, Lk 4:16). In training his disciples, he chose to use mentorship and teaching as their ministerial training approach (Mk 3:13-15, Mk 6:1-2). This therefore, implies that ministerial formation can be formal and informal in nature depending on the requirements of a particular church or organisation (White 2019:4).
According to the World Council of Churches:

A church without proper and qualified theological education systems tends to diminish itself or ends in Christian religious fundamentalism. A church with properly developed theological education qualifies itself for greater degrees of interaction and outreach to the different levels and challenges in its society, as well as to a deeper commitment to holistic Christian mission. (Lorke \& Werner [eds] 2013:116)

In an interview with the missionary head of South Africa, Rev. Abraham Quarshie in August 2019, it was noted they do not have any formal approach for the training of the ministers and pastors assigned to manage various branches of the Christ Apostolic Church International in South Africa. According to him, training is done informally through monthly meetings and seminars with the leaders.

Unlike the Christ Apostolic Church International, the Church of Pentecost has a clearly defined and functional policy on the training of their ministers. This policy is enshrined in a 5-year (2013-2018) policy document called Vision 2018. The policy states that:

The ministry is challenged by the dynamics and trends of the contemporary environment. This, therefore, calls for a constant upgrading and increasing of knowledge and skills in modern trends for all ministers. To be more effective in today's ministry is to engage in life-long learning processes, which are sharpened through prayer. Provision therefore needs to be made for relevant resources and training opportunities for the ministers. Hands-on training also needs to continue. (The Church of Pentecost 2014:7)

Further, the policy also covered plans for establishing ministerial training for external branches, including South Africa (The Church of Pentecost 2014:33-36) as well as policy for their International Missions (The Church of Pentecost 2014:57-60). The South African mission of the church established Pentecost Theological Institute in 2016 to enhance professional and theological training of their ministers. The institute had its maiden graduation on 23 February 2018. In March 2019, the institute began Higher Education Certificate in Theology programme. The programme is aimed at lay leadership development within and outside the Church of Pentecost (Quampah 2019a:3).

\section{Contextualisation of Ghanaian Classical Pentecostal in South Africa}

Contextualisation of the gospel is very important when a migrant church decides to reach out to people in their host context. In doing this, the migrant church or missionary would have to deal with the indigenes of his or her host country or town in the context of the host culture and worldview. The context forms the basis through with the migrant church or missionary integrate into the cultural dynamics of his or her target converts (Kraft 2000:386-338). Guder (2000:83) submits that it is the responsibility of migrant churches and missionaries to translate the gospel into their new culture. This approach is more than translating the gospel into the language of the host culture. It is rather the 
expression of one's experienced faith in the light of the new cultural context.

Contextualisation of the gospel in this article aimed at the fact that migrant churches or missionaries through missional discernment should make their presence and the gospel relevant to their host context. In this light, Asamoah-Gyadu (2013a:11) defines African Christianity as the expressions of Christianity informed by the primal worldviews embedded in African culture and available also on the global stage. In that respect, the lordship of Jesus Christ could be said to constitute the basis of all Christianity, but the faith is not expressed the same way across cultures precisely because cultures and peoples differ.

White and Ntsiful (2018) posit that:

Jesus' ministry was first of all incarnational (Jn 1:14; Mt 1:23; 2 Cor 5:19). A working definition of incarnational ministry is the immersion of one's self into the local culture and 'becoming Jesus' to that culture or environment. Incarnational ministry seeks to dispense ministry from a distance and embraces ministry up close and personal. In doing this, the love of God and the gospel of Christ are incarnated or embodied by the person ministering (Migrant churches/missionaries). The church is called to live an incarnational missional life. The core of the concept of incarnational ministry is to live the good news rather than preach the good news; by influencing one's context with the gospel. (p. 7)

The international mission policy of the Church of Pentecost (2014) states that:

[C]onscious effort will be made to reach foreigners, indigenous people and the youth in the diaspora with the gospel, taking cognizance of their cultures and making full use of modern technology. (pp. 58-59)

This policy has been strictly adhered to by the Southern African mission of the Church of Pentecost. They have integrated South African indigenes in their pastorate and national leadership (The Church of Pentecost, South Africa 2019b). According to the Apostle Dr. Dela Quampah, the CoP - South Africa has 40\% indigenous membership, 10\% are other African nationals and 50\% Ghanaians. ${ }^{6}$ Although the Christ Apostolic Church International in South Africa has also made efforts in this aspect, a lot more is required in achieving this goal. As part of the contextual integration process of both churches, they do incorporate South African songs in their church service and other religious functions.

\section{Impact of migrant Pentecostal Churches in Pretoria, South Africa}

This subheading discusses some of the social impact both churches have made in South Africa. This would help us appreciate the fact that they did not only come to evangelise but also to create social and spiritual capital for missional purposes.

6.Personal interview with him on 16 August, 2019, at the national headquarters of the Church of Pentecost, Kempton Park South Africa.

\section{Discipleship and social transformation}

Discipleship plays a major role in social transformation. As part of the great commission, Jesus Christ gave the church the task of disciplining the nations by teaching converts to live practical Christian life (Mt 28:19-20). What defines Pentecostals is the experience of the Holy Spirit in transformation, radical discipleship and manifestations of the acts of the power of God amongst His people (AsamoahGyadu 2013b:10-11). Bosch refers to the mission as the disciple-making assignment of the church (2001:56).

Discipleship is one of the ways to reduce crime and to promote moral uprightness in society. Ghanaian Classical Pentecostal churches have strict policy on immoral behaviour amongst their members (Asamoah-Gyadu 2013c:22). One of the areas the Church of Pentecost and the Christ Apostolic Church International have made an impact in South Africa is in their radical approach to discipleship. Both churches have made conscious efforts to disciple their new converts and also strengthen the moral behaviour of their members through their Sunday school and mid-week, Bible study programmes. This has also gone further to include activities of the various ministries and departments in the church. In their view, discipleship is a progressive way of instituting good morals in people and in effect transforming their communities (The Church of Pentecost 2014:11, 16; White 2018:131-133).

\section{Donations and social services}

Social services/diaconal ministry is part of the missional call of the church. In the light of this, both churches have done very well in this area in South Africa. The 2018 annual report of the Church of Pentecost and the Christ Apostolic Church International reported various donations they have participated in, both at the district and local church levels. Many of such donations went to orphanages and homeless people. The Christ Apostolic church reported that they annually organise food buzzer in Sunnyside, Pretoria dubbed 'I care'. This is aimed at feeding the homeless and sharing the gospel with them.

Apostle Dela Quampah reported that they sometimes distribute food to homeless people and people in need. The church of Pentecost has also established a crèche as part of their contribution to the development of children in Sunnyside, Pretoria. One of the motives for the establishment of the school is to help develop the enrolled children morally and in fear of God at their tender age.

\section{Cross-culture integration and inclusiveness}

The churches serve as places for spiritual, social and cultural support. Members are taught to be hard-working and contribute their share to South Africa in whatever way possible. Migrant communities are largely characterised by networks, activities and life-patterns that entangle both their 'old home' and 'new home' societies, as well as with other host contexts (Adogame 2010:56-57). 
Members of the migrant churches see themselves as the anchors for mutual support and care. Their support is seen when one is in need, bereaved, marrying and during child naming. In an interview with Rev. Abraham Quarshie, the Christ Apostolic Church International Mission head for South Africa reported that the church has done her best to play the role of inclusiveness by bringing on board members who are South African to be part of the leadership and management board. He further noted that as the church is also made up of people from diverse culture, structures are in place for cultural integration in the way things are done in the church. ${ }^{7}$

It was observed that there are also cross-culture and transborder marriages in both churches used for the study. These marriages have also strengthened the bond of unity in the church in the light of diverse cultures present.

\section{Conclusion}

This article discusses migration from a missional perspective using Ghanaian Classical Pentecostal churches in South Africa as a case study. The article argues that biblical record provides us enough information on the fact that, God has on several occasions used the migration of people to fulfil his missional agenda in spite of the cause for migration.

The article submits that Pentecostalism and migration have always moved together. The article in this light discussed the history of the Church of Pentecost, South Africa, and the Christ Apostolic Church International, South Africa. The article also considered issues concerning their leadership development, transfer of missionaries from Ghana and its implications, as well as their concept of contextualisation. The article submits that it is time for both churches to start thinking of decolonising their foreign mission churches by helping them to have autonomous status. The article concluded with some of the impact made by both churches in South Africa.

\section{Acknowledgements}

The author would like to acknowledge the support and information he had from Rev. Abraham Quarshie of the Christ Apostolic Church International, Pretoria, South Africa. The same honour goes to Apostle Dela Quampah of the Church of Pentecost, South Africa. They both supplied me with all the needed information and documents required for the research.

\section{Competing interests}

The author has declared that no competing interests exist.

\section{Authors' contribution}

I declare that I am the sole author of this research article.

7.Personal interview with him on 14 August, 2019 , at the national headquarters of Christ Apostolic Church International, Sunnyside, South Africa.

\section{Ethical considerations}

This article followed all ethical standards for a research, more especially for the interviews with the South African national missionary leaders of the two churches used for the study.

\section{Funding information}

This research received no specific grant from any funding agency in the public, commercial or not-for-profit sectors.

\section{Data availability}

Data for the study would be well kept for the next 5 years for academic and verification purposes.

\section{Disclaimer}

The views and opinions expressed in this article are those of the authors and do not necessarily reflect the official policy or position of any affiliated agency of the authors.

\section{References}

Adogame, A., 2010, 'Transnational migration and Pentecostalism in Europe', PentecoStudies 9(1), 56-73. https://doi.org/10.1558/ptcs.v9i1.56

Anderson, G.H., Coote, R., Horner, N. \& Philips, J. (eds.), 1994, Mission legacies: Biographical studies of leaders of the modern missionary movement, Orbis Books, Maryknoll, New York, NY.

Asamoah-Gyadu, J.K., 2005, African charismatics: Current developments within independent indigenous Pentecostalism in Ghana, Brill, Leiden,

Asamoah-Gyadu, J.K., 2013a, Prayer, power and empowerment: Migration and diaspora mission, A lecture in honor of Hendrik Kraemer held at Protestant Theological University, Amsterdam.

Asamoah-Gyadu, J.K. 2013b, Contemporary Pentecostal Christianity: Interpretation from an African context, Regnum Books International, Eugene, OR.

Asamoah-Gyadu, J.K., 2013c, 'The promise is for you and your children: Pentecostal spirituality, mission and discipleship in Africa', in M. Wonsuk \& R.R. Kenneth (eds.), Regnum Edinburgh centenary series, vol. 14, p. 22, Regnum Books International, Oxford.

Bevans, S.B., 2013, 'Migration and mission: Pastoral challenges, theological insights', in E. Padilla \& P.C. Phan (eds.), Contemporary issues of migration and theology, Christianities of the World, pp. 157-177, Palgrave Macmillan, New York, NY.

Bosch, J.D., 2001, Transforming mission: Paradigm shifts in theology of mission, Orbis Books, Maryknoll, New York, NY.

Christ Apostolic Church International, 2018, Constitution, CACI Press, Accra.

Department of Home Affairs, 2020, General information about temporary residence visas, viewed 04 November, 2020, from http://www.dha.gov.za/index.php/ immigration-services/temporary-residency.

Guder, D.L., 2000, The continuing conversion of the church, William B Eerdmans Publishing Company, Grand Rapids, MI.

Hanciles, J.J., 2008, Beyond Christendom: Globalization, African migration, and the transformation of the west, Orbis Books, New York, NY.

Kgatle, M.S., 2017, 'The unusual practices within some Neo-Pentecostal churches in South Africa: Reflections and recommendations', HTS Teologiese Studies/ Theological Studies 73(3), a4656. https://doi.org/10.4102/hts.v73i3.4656

Kgatle, M.S., 2019, 'Reimagining the practice of Pentecostal prophecy in Southern Africa: A critical engagement', HTS Teologiese Studies/Theological Studies 75(4), a5183. https://doi.org/10.4102/hts.v75i4.5183

Kraft, C.H., 2000, Culture, worldview and contextualization', in R.D. Winter \& S.C. Hawthorne (eds.), Perspectives on the world Christian movement: A reader, $3 \mathrm{rd}$ edn., pp. 384-396, William Carey Library, Pasadena, CA.

Larbi, E.K., 2001, Pentecostalism: The eddies of Ghanaian Christianity, Blessed Publications, Accra.

Livingstone, E.A. (ed.), 2013, The concise Oxford Dictionary of the Christian Church, 3rd edn., Oxford University Press, Oxford.

Lorke, M. \& Werner, D. (eds.), 2013, Ecumenical visions for the 21st century: A reader for theological education, World Council of Churches Publications, Geneva.

Lovett, L., 1975, 'Black origin of Pentecostal movement', in V. Synan (ed.), Aspects of Pentecostal charismatic origin, Logos International, New Jersey.

Markin, A.J., 2018, 'Spirit and mission: The church of Pentecost as a growing African Pentecostal denomination', A PhD thesis submitted to South African Theological Seminary, Pretoria. 
Miller, D.R., 2006, From Azusa to Africa to the Nations, Life Publishers International, Springfield.

Quampah, D., 2019a, The Church of Pentecost, South Africa mid-year report (January-June, 2019).

Quampah, D., 2019b, The Church of Pentecost, South Africa mid-year comparative statistics (January-June, 2019).

Resane, K.T., 2017, “'And they shall make you eat grass like oxen" (Daniel 4:24): Reflections on recent practices in some New Charismatic Churches', Pharos Journal of Theology 98(1), 1-17.

Roxburgh, A.J.,1998, 'Equipping God's people for mission', in D. Guder (ed.), A vision for the sending of the church in North America, pp. 183-220, William B. Eerdmans Publishing Company, Grand Rapids, MI.

The Church of Pentecost, 2014, Vision 2018: Five-year vision for the Church of Pentecost covering the period 2013-2018, Pentecost Press, Accra.

The Church of Pentecost, 2017, Ministers handbook, Pentecost Press Limited, Accra.

The Church of Pentecost, South Africa, 2019a, About, viewed 15 August 2019, from https://pentecostsa.org/index.php/national-heads-message/.

The Church of Pentecost, South Africa, 2019b, National head's message, viewed 15 August 2019, from https://pentecostsa.org/index.php/national-heads-message/.

The Church of Pentecost, South Africa, 2019c, National executive, viewed 15 August 2019, from https://pentecostsa.org/index.php/leadership/.

Walker, D.O., 2010, 'The Pentecost fire is burning: Models of mission activities in the church of Pentecost', PhD thesis, University of Birmingham.
Walls, A., 2014 'Mission and migration: The diaspora factor in Christian history', in C.H. Im \& A. Young (eds.), Global diasporas and mission, pp. 20-21, Regnum Books International, Oxford.

Wild-Wood, E., 2008, Migration and Christian identity in Congo (DRC), Koninklijke Brill, Leiden.

White, P., 2016, 'Pentecostal mission spirituality: A study of the Classical Pentecostal churches in Ghana', Missionalia: Southern African Journal of Missiology 44(3), 251-262. https://doi.org/10.7832/44-3-101

White, P., 2017, 'Pastoral transfers in classical Pentecostal churches in Ghana: Implications on mission and the Pastoral family', Ghana Journal of Religion and Theology 7(1), 123-136.

White, P., 2018, 'Pentecostal pneumatology in Ghanaian Christian mission', Trinity Journal of Church and Theology 19(3), 126-141.

White, P., 2019, 'The future of African Pentecostal Scholarship: The role of the church and academia', A paper presented at a conference organised by Southern African Missiological Society, held at the North-West University, Potchefstroom Campus, January 15-17.

White, P. \& Ntsiful, J., 2018, 'A revisit of the ministerial concept of the Lay and full-time ministers in classical Pentecostal churches in Ghana and its missional implication', Studia Historiae Ecclesiasticae 44(1), 12, https://doi.org/10.25159/2412$4265 / 3826$

World Economic Forum, 2017, Migration and its impact on cities, viewed 12 August 2019, from http://www3.weforum.org/docs/Migration_Impact_Cities_report 2017_low.pdf. 